\title{
DESIGNING JOURNEYS TO THE SOCIAL WORLD: HEGEL'S THEORY OF PROPERTY AND HIS NOBLE DREAMS REVISITED ${ }^{1}$
}

\author{
Haochen Sun
}

\begin{abstract}
The conventional readings of Hegel's theory of property show that property plays an important role in developing human individuality. In this paper, I repudiate the conventional readings and offer a new interpretation of Hegel's theory of property. I aim to show that Hegel's theory of property provides a vantage point for us to rethink the relationship between persons and the society in general and the nature of property in particular. Situated in the whole picture of Hegel's social theory of freedom, I demonstrate that Hegel sees property as a social institution that plays a crucial role in shaping human individuality as well as sociability.
\end{abstract}

KeYwORDs: Property; individuality; mutual recognition; sociability; ethical life; exclusive rights; ethical duties

\section{CONTENTS}

INTRODUCTION

I. The Conventional Interpretations of Hegel's Property Theory 34

II. Shaping Individuality: Private Property and the Freedom of Being a Person 36

A. Externalization and Internalization of Free Will 37

B. Mutual Recognition of the Abstract Identity as Persons 40

III. Shaping Sociability: Private Property and the Freedom of Being a Social MEMBer

A. Social Membership of Ethical Life

I.This paper was presented at the Society for European Philosophy and the Forum for European Philosophy Joint Conference 2007 (Brighton, UK) and the Workshop on Property and Political Theory: Historical and Contemporary Understandings (Manchester, UK). I am grateful to the participants at these two conferences for their helpful comments. All references in the text marked $P R$ are to G. W. F. Hegel, Elements of the Philosophy of Right, trans. H. B. Nisbet, Cambridge, Cambridge University Press, I99I, PM are to G. W. F. Hegel, Philosophy of Mind, trans. W. Wallace \& A. V. Miller, Oxford, Oxford University Press, 2007, PhG are to G. W. F. Hegel, Phenomenology of Spirit, trans. A. V. Miller, Oxford, Clarendon Press, 1977, and VPR I7 are to G. W. F. Hegel, Lectures on Natural Right and Political Science, trans. J. Michael Stewart and Peter C. Hodgson, Berkeley, University of California Press, 1995. Both 'he' and 'him' are used in this paper in a gender-neutral sense. 


$\begin{array}{lr}\text { B. Private Property and Social Membership } & 47 \\ \text { I. The Well-Being of Social Members } & 47 \\ \text { 2. Social Recognition of the Concrete Identity as Social Members } & 49 \\ \text { IV. Social Institutions, Property Rights, AND EthiCal Duties } & 5^{\mathrm{I}} \\ \text { A. Protecting Property Rights } & 5^{2} \\ \text { B. Enforcing Ethical Duties } & 54 \\ \text { Conclusion } & 5^{8}\end{array}$

\section{INTRODUCTION}

The conventional interpretations of Hegel's theory of property show that property plays an important role in developing human individuality through the person-to-thing relationship. In this paper, I seek to repudiate the conventional interpretations by demonstrating that they are narrow-minded and unfaithful to Hegel's thought on property. I then offer a new interpretation of Hegel's theory of property. I aim to show that Hegel's property theory provides a vantage point for us to rethink the relationship between persons and the society in general and the nature of property in particular. Situated in the whole picture of Hegel's social theory of freedom, I demonstrate that Hegel sees property as a social institution that plays a crucial role in shaping human individuality as well as sociability. On the one hand, mediated by the institution of property, a person nurtures and develops individuality or personal freedom in the social world consisting of things and other persons. On the other hand, the institution of property facilitates the cultivation of sociability by helping human beings become members of our society. Furthermore, social institutions in the Hegelian ethical life act as the indispensable catalyst for empowering property to spark the synergies between human individuality and sociability so as to actualize freedom for all human beings.

\section{THE CONVENTIONAL INTERPRETATIONS OF HEGEL'S PROPERTY THEORY}

\section{A. The Embodiment Thesis and Person-To-Thing Relationship}

Central to the conventional interpretations of Hegel's property theory is the embodiment thesis that is focused primarily on the way in which persons develop human individuality through their pure relations with things in their possession. To this end, some commentators argue that Hegel justifies the legitimacy of property based on the necessity of individuals' embodiment of their will into things. The act of embodying establishes the relationship between an individual and the thing in his possession. The mere forming of this kind of relationship, in their view, is sufficient to lay the foundation for individuals to nurture and develop human individuality. Jeremy Waldron, for example, concludes that ' $[\mathrm{t}]$ he importance of property to individual wills [in Hegel's property theory] is this: the actions that an individual performs on or with this object now may constrain or determine the actions that he can perform on or with it later. This is how an object 
can embody a will — by registering the effects of willing at one point of time and forcing an individual's willing to become consistent and stable over a period.'2 Similarly, J. E. Penner argues that Hegel 'explains property as a relation between persons and things which is essentially determined by the nature of persons and things, specifically by the fact that persons have wills and things do not'. ${ }^{3}$ Moreover, Margaret Jane Radin's pioneering work on personality theory of property that focuses on 'personal embodiment or self-constitution in terms of 'things"' draws on her individualist interpretation of the way in which Hegel justifies the institution of property through the act of embodying individual will in things and the subsequent creation of person-to-thing relations.

\section{B. Property, Individuality, and Personal Freedom}

On the other hand, the conventional interpretations are preoccupied with analyzing how Hegel explains the role of property in empowering human beings to become persons or developing their own individualities. Put differently, Hegel's theory focuses on the role of property in fostering and promoting personal freedom. For example, Alan Patten argues that 'Hegel elaborates and defends ... a developmental thesis about the connection between individual freedom and private property. According to this thesis, having at least a minimal amount of private property is essential to the development and maintenance of the capacities and self-understandings that make up free personality. ${ }^{5}$ Similarly, some other scholars' interpretations focus on the connection between the institution of property and the development of personal freedom. ${ }^{6}$

\section{The Limitations of the Conventional Interpretations}

The core problem of the conventional interpretations of Hegel's property theory, in my opinion, stems from the interpretative methodology employed by the scholars who focus exclusively on the 'Abstract Right' chapter of Hegel's Philosophy of Right dealing with the nurturing of human individuality or personal freedom. ${ }^{7}$ In this way, the conventional interpretations were made without looking broadly at Hegel's social theory of freedom. For example, they barely discuss whether Hegel considers the role of property in shaping human sociability and developing ethical life and human society at large.

2. Jeremy Waldron, The Right to Private Property, Oxford, Oxford University Press, I988, p.373.

3. J.E. Penner, The Idea of Property in Law, Oxford, Oxford University Press, I997, p.r6g.

4. Margaret Jane Radin, 'Property and Personhood', Stanford Law Review, Vol. 34, I982, pp.958.

5. Alan Patten, Hegel's Idea of Freedom, Oxford, Oxford University Press, 1999, p. I40.

6. See, for example, Justin Hughes, The Philosophy of Intellectual Property, Georgetown Law Journal, vol. 77, I988, p.33 ('In his property theory, however, Hegel focused on the immediate freedom of an individual'); J.W. Harris, Property and Fustice, Oxford, Oxford University Press, I996, pp.230-237; Renato Cristi, Hegel on Freedom and Authority, Cardiff: University of Wales Press, 2005, pp.76-9o; Allen W. Wood, Hegel's Ethical Thought, Cambridge, Cambridge University Press, I990, pp.94-ı07.

7. See, for example, Thom Brooks, Hegel's Political Philosophy: A Systematic Reading of the Philosophy of Right, Edinburgh, Edinburgh University Press, 2007, p.37 ('Many commentators mistakenly hold that Hegel's complete views on property are contained in abstract right'.). 
Some parts of the conventional interpretations even hold that Hegel's 'individualistic' thought on property cannot fit comfortably with, and may run counter to, his general theory of social freedom in ethical life. For example, preoccupied with examining the 'embodiment' and 'personal freedom' theses of Hegel's theory, Jeremy Waldron points out that 'Hegel's account of civil society [in ethical life] fits well, in many respects, with his account of the importance of private property.'

The isolated interpretative methodology employed by the conventional interpretations, therefore, results in the problem that Hegel's theory of property turns out to be very individualistic and irreconcilable with his social theory of freedom which teaches that the selfactualization of freedom requires a varied degree of reliance on otherness. ${ }^{9}$ Hegel's idea of freedom fundamentally differs from the liberal notion of freedom in that he 'abandons the concept of freedom as independence when he stresses that the self must live through others and in the world?. ${ }^{10}$ As the embodiment of the independence from as well as dependence on otherness, freedom, in Hegel's view, can be only developed in social settings.

In this paper, I aim to repudiate the conventional interpretations and offer a new interpretation by situating Hegel's thought on property in the whole picture of his social theory of freedom. On the one hand, I re-examine the role of property in shaping human individuality based on his idea of externalization and internationalization of free will and further on his idea of mutual recognition. As I will show, my interpretation profoundly differs from the embodiment thesis and the focus on the person-to-thing relationship that are prevalent in the conventional interpretations. On the other hand, I discuss the ways in which Hegel considers the role of property in shaping human sociability. To do so, I show how property contributes to improving the well-being of human beings as social members and achieving social recognition of such human identity. This part of my interpretation sheds new light on the social thesis embedded in Hegel's theory of property, to which the conventional interpretations turn a blind eye. Furthermore, I explore how Hegel designs the building blocks of the property system based upon his social theory of freedom, which is barely discussed in the conventional interpretations.

\section{SHAPING INDIVIDUALITY: PRIVATE PROPERTY AND THE FREEDOM OF BEING A PERSON}

The overall task that Hegel aims to accomplish in the Philosophy of Right, as he points out at the very beginning of this book, is to examine the concept of freedom and how it can be actualized. ${ }^{\text {II }}$ Hegel sees the actualization of freedom as a historical process that

\footnotetext{
8. Waldron, The Right to Private Property, P.374.

9. PM $\S_{382} \mathrm{~A}$ ('But the freedom of mind is not merely an independence of the Other won outside the Other, but won within the Other; it attains actuality not by fleeing from the Other but by overcoming it'); PR §7A. See also, Wood, Hegel's Ethical Thought, pp.44-49; Frederick Neuhouser, Foundations of Hegel's Social Theory, Cambridge, Harvard University Press, 2000, pp. I9-20; Michael O. Hardimon, Hegel's Social Philosophy: The Project of Reconciliation, Cambridge, Cambridge University Press, I994, p.I I4.

Io. Frederick Beiser, Hegel, London: Routledge, 2005, p.202.

II. PR § I ('The subject-matter of the philosophical science of right is the Idea of right - concept of right and its actualization').
} 
entails different stages of human and social developments. ${ }^{12}$ One stage of such development deals with the freedom of being a person, namely personal freedom. In this realm of development, human individuality flourishes and personal freedom develops through the interactions between the individual and the thing, and further among individuals with the exclusive possession of things.

\section{A. Externalization and Internalization of Free Will}

To be a person, one must, as Hegel points out, posit oneself in a way that is different from others. The determinations of interpersonal differences largely stem from the ways in which each person makes a multitude of varied choices to satisfy their own natural drives, desires, and inclinations. According to Hegel, having an external sphere of freedom is indispensable for actualizing the personal choice-making process. 'The person must give himself an external sphere of freedom in order to have being as Idea.' 13 This is because an external sphere provides the space within which one is left free to choose the individualized ways to satisfy his natural drives, desires, and inclinations. In doing so, one gradually develops his own distinctive contents and form of individuality.

For Hegel, things like land, stones, and animals have no free will. They are by nature external not only to themselves but to all human beings. ${ }^{14}$ Therefore, a thing naturally constitutes the external sphere a person can take control of for making his own choices. In this context, a person can manifest his supremacy over a thing by placing his individual will in it:

A person has the right to place his will in any thing. The thing thereby becomes mine and acquires my will as its substantial end (since it has no such end within itself), its determination, and its soul - the absolute right of appropriation which human beings have over all things. ${ }^{15}$

The act of placing human will in a thing, as Hegel observes above, would amount to a person's exclusive control over it. This is because he sees the act of placing one's individual will in a thing as a means to the end of developing individuality or personal freedom. For Hegel, the reasons for this are twofold.

On the one hand, Hegel thinks that a person can achieve the assertion of the selfconsciousness of being free by going through a judgment-making process for himself as to whether and how he should place his individual will in a particular thing. There are, as Hegel points out, three means by which taking possession of things can be accomplished by the act of placing of the will, and each of the means involves the individualized judgment-making process. ${ }^{16}$ First, one's physical seizure of a thing enables him to create a con-

\footnotetext{
I2. PR $\S \S 3 \&$ 3A; VPR I7 $\S 8$ ('Right has manifold stages....).

I3. PR $\$ 4 \mathrm{I}$

I4. PR $\$ \$ 42-43 ;$ VPR I7 $\$ 15$.

I5. PR $\$ 44$. See also, PM $\$ 489$ ('The predicate of mine, which the thing obtains through the judgment of possession initially in the external appropriation, is for itself merely practical, but here it has the meaning that I put my personal will into the thing.); VPR I7 §i6.

I6. PR $\$ 54$
} 
nection with the thing concerned, because he is immediately present in this possession and his will thus also discernible in it. ${ }^{17}$ Second, one can also give form to things in order to shape their characters based upon his personal knowledge and volition. ${ }^{18}$ This way of taking possession of things may include cultivating land, building a windmill, or training animals. ${ }^{19}$ Thirdly, one can designate ownership of things by putting his mark on them, for instance, building a fence outside his house. ${ }^{20}$ All these forms of taking possession of things are carried out by a person for himself as he sees fit. He decides to do it simply for his own purposes based upon his desires, preferences, and inclinations. ${ }^{21}$ In doing so, he makes a judgment for himself by deciding whether he should put his will in a thing and thereby take possession of it. The more judgments of this kind he makes for himself, the more he knows about his own free will as manifested by taking possession of things. Hence the judgment-making process of this type is the most direct self-assertion and self-positing of one's consciousness of being a free person. As Hegel observes, 'possession becomes property insofar as the I who possess it is a free will that wills to possess it. Thus in property my will has become objective to me. In property my will has determinate existence, and this determinate existence of the will must be respected. Mere possession is not to be respected, but my free will, that has placed the predicate 'mine' in a thing, constitutes possession as property. With this assertion of right begins, for right is freedom as such. ${ }^{22}$

On the other hand, Hegel holds that a person's taking possession of things through placing his will in them empowers himself to reinforce the self-consciousness of his status as a free being. As Hegel observes, 'the circumstance that I, as free will, am an object to myself in what I possess and only become an actual will by this means constitute the genuine and rightful element in possession $\ldots{ }^{623}$ In this sense, the thing that I possess acts as a mirror in which I can perceive the existence of my own free will. Because I put my will in the thing I possess, I can treat the thing as an integral part of my free will and further my image as being a free will. ${ }^{24}$ I take possession of things and at the same time they mirror back my free will to me. Thereby, I become aware that I, as a free being, am an object to myself and I am definitely no longer an alien to my own self, because I realize that I am the possessor of my own free will that is put in the thing. In this regard,

\footnotetext{
I7. $\mathrm{PR} \oint 55$.

I8. $\mathrm{PR} \S 56$.

19. PR $\S 56 \& 56$ A.

20. PR $\S 58$.

2I. PR $\$ 45$ ('To have even external power over something constitutes possession, just as the particular circumstance that I make something my own out of natural need, drive and arbitrary will is the particular interests of possession?.); G. W. F. Hegel, Vorlesungen über Rechtsphilosophie Karl-Heinz Ilting (ed.), vol. 4, Stuttgart-Bad Cannstatt, Frommann-Holzboog, I973, \$4:I86 ('A possession means that I have something in my external power, even if that something is natural. Possession hangs together with my needs, drives, and special interests. I possess something because I need to have it....).

22. Hegel, Vorlesungen über Rechtsphilosophie.

23. PR $\$ 45$.

24. PR $\$ 4 \mathrm{~A}$ ('When I think of an object, I make it into a thought and deprive it of its sensuous quality; I make it into something which is essentially and immediately mine. For it is only when I think that I am with myself, and it is only comprehending it that I can penetrate an object, it then no longer stands opposed to me, and I have deprived it of that quality of its own which it had for itself in opposition to me.).
} 
Hegel points out that 'I look at myself in my property' and thereby in property 'I regard myself as free'. ${ }^{25}$ With the recurring experience of taking possession of things, a person is thereby empowered to continuously develop and promote the self-understanding of his status as 'a willing and truly affirmative agent'. ${ }^{26}$

As shown above, a person's individual will, in fact, goes through a two-way process of movement through the act of taking possession of things: the externalization and subsequent internalization of free will. ${ }^{27}$ By externalizing individual will into things, a person obtains an external sphere that is necessary to the self-assertion of his consciousness of being free and development of his individuality. By subsequently internalizing the individual will mirrored back by the thing in his possession, he further reinforces his consciousness of being free.

In addition to the act of taking possession of things, the process of externalizing and internalizing free will is further deepened by a person's making choices to use or alienate the things in his possession. Since I am in control of a thing, I can satisfy my need through 'the alteration, destruction, or consumption of the thing. ${ }^{28}$ In doing so, I continue to place my individual will in the thing through the process of making a choice as to whether and how I should use the thing. If I make the whole use of a thing, my individual will would fully penetrate the thing. ${ }^{29}$ In this context, it means that I internalize my will in the thing and externalize my will out of it to the fullest extent possible. On the other hand, the thing is negated by me because it 'is reduced to a means of satisfying my need'.$^{30}$ In this process, I look at the thing to the fullest extent possible, the thing mirror back my will to the fullest extent possible as well, and therefore I internalize my will to the fullest extent possible. Given that I make the externalization and internalization of my will to the fullest extent, I presumptively become the sole owner of thing ${ }^{31}$ and my '[o]wnership is therefore essentially free and complete ownership. ${ }^{32}$

Moreover, Hegel holds that persons are at liberty to alienate their properties. Things are by nature selfless and have no will. I am at liberty to place my will in a thing as a way to manifest my supremacy over it. As long as the thing is external to me, ${ }^{33} \mathrm{I}$ am also at liberty to withdraw my will from a thing I possess as a way to manifest my supremacy over it. I am at liberty to withdraw my will by simply abandoning the thing or allowing another person to internalize his will in it. In this way, I demonstrate to my own self that I am indeed the master of things in my possession, and I can treat them in any way at

25. G. W. F. Hegel, Die Philosophie des Rechts: die Mitschriften Wannenmann (Heidelberg I8I7/I8) und Homeyer (Berlin I8I8/I9), Karl-Heinz Ilting (ed.), Klett-Cotta, I983, 224 \& 225.

26. PR $\$ 59$ A.

27. VPR I7 §I6 ('Though possession, on the one hand, I become external... ‘.).

28. PR $\S 59$.

29. PR \$62 (If the whole extent of the use of a thing were mine, ... the thing as mine would be wholly penetrated by my will... ‘). See also, PR §6r.

3o. PR $\S 59$ A.

3I. PR §6I ('If I have the whole use of the thing, I am its owner; and beyond the whole extent of its use, nothing remains of the thing which could be the property of someone else'.).

32. PR $\S 62$.

33. PR $\$ 65$. 
my disposal. ${ }^{34}$ The liberty to alienate things, therefore, is the best way to show that I am in full possession of the thing. I will to alienate my property entirely based on my own choice and I then entirely withdraw the will I placed in the thing concerned. Hence, my alienation of a thing indicates that I decide to stop externalizing my will and to entirely internalize back all the will I have externalized in it.

\section{B. Mutual Recognition of the Abstract Identity as Persons}

As shown above, Hegel sees taking possession of things by externalizing will in them as the condition for a person to acquire property. Through the interaction between individual will and things in the act of taking possession, using, or alienating, a person obtains the external sphere of personal freedom. This external sphere is by nature private and exclusively belongs to an individual as the possessor of the thing concerned. Interestingly, in addition to this condition, Hegel adds a second condition of acquiring property by requiring that one's ownership of a thing must be recognized by others. $\mathrm{He}$ explains this point as follows:

My inner idea and will that something should be mine is not enough to constitute property, which is the existence of personality; on the contrary, this requires that I should take possession of it. The existence which my will thereby attains includes its ability to be recognized by others. ${ }^{35}$

This passage shows that, while property rights can be asserted and exercised by persons through their acts of taking possession of things, they are not fully actualized in the social world unless recognized by others. In the Philosophy of Right, Hegel emphasizes this point: 'The concept of property requires that a person should place his will in a thing, and the next state is precisely the realization of this concept. My inner act of will which says that something is mine must also become recognizable by others'. ${ }^{36}$ The recognition of property rights, as Hegel points out, is mutually and reciprocally achieved in a way to fulfill the second part of the imperative set out by him for the commandment of property right: 'be a person and respect others as person.s'37 This two-part imperative can only be realized as a whole, and each part should be fulfilled simultaneously. With the exclusive control over certain things, one will to be a free person with his own distinctive individuality (to be a person). Yet Hegel thinks that one's personal freedom needs to be recognized by others. Without this kind of recognition, personal freedom is, in fact, not realizable in the social world. Since property constitutes a person's external sphere of personal freedom, the recognition of his control over property from others is the way in which he is recognized and respected as a free person. In reciprocity, he recognizes others' control over their properties and thereby recognizes and respects others as persons as well. In Hegel's earlier works, he repeatedly emphasizes

\footnotetext{
34. PR $\S_{5} \mathrm{~A}$ (pointing out that 'alienation is regarded as a true mode of taking possession').

35. $\mathrm{PR} \S 5 \mathrm{I}$.

36. PR $\S_{5} \mathrm{I}$

37. PR $\S_{36}$.
} 
the requirement of mutual recognition when he talks about property. For example, he points out that 'Taking possession is the empirical act of seizure, and this is to be justified through recognition. It is not justified merely by virtue of its having occurred ${ }^{3}{ }^{8}$ Moreover, he even concludes that 'The essential being of ownership is the determinate existence of its right-governed absolute aspect, namely that in ownership persons recognize one another as persons. ${ }^{39}$

Thus, it is clear that Hegel sees mutual recognition of property rights as an indispensable step to actualizing personal freedom..$^{\circ}$ He succinctly encapsulates the reasons for the need of mutual recognition and how persons can achieve mutual recognition of ownership in Philosophy of Mind:

In property the person is joined together with himself. But the thing is an abstractly external thing, and the I in it is abstractly external. The concrete return of me into myself in the externality is this: I, the infinite relation me to myself, am as a person the repulsion of me from myself, and have the embodiment of my personality in the being of other persons, in my relation to them and in recognition of by them, which is thus reciprocal. ${ }^{41}$

To understand this passage, we must read it together with what Hegel writes in Phenomenology of Spirit and Philosophy of Mind with respect to his theory of mutual recognition. For Hegel, a human being cannot achieve a full self-consciousness of being a free person and actualize personal freedom if he relies only on things in his possession and the external sphere afforded by them. By internalizing or externalizing his will, a person takes possession of an object and subsequently uses or alienates it. By doing so, he makes choices as to whether and how he may interact with the selfless object. His making of choices, however, is based upon his natural desires for food, water, safety, etc. Against this backdrop, his self-consciousness of being free, in fact, hinges upon the satisfaction of natural desires through his sole relationship with that object in his possession. Yet the person still faces the need to satisfy the endless waves of potential desires, and the satisfaction derived from a single external object is by no means sufficient to respond to the successive waves of desires. For this reason, his preoccupation with the ebb and flow of his desires keeps him revolving around selfless and impersonal objects. He would, in this context, run the risk of 'yielding [himself] to the incessant renewal of desire' ${ }^{22}$ to obtaining external objects. Rather than achieving the self-consciousness of being a free person, he may well lose his independence and then become a 'slave' of selfless things or his desires of possession due to his relentless reliance upon things to satisfy his desires. This endangers the actualization of his personal freedom.

38. G. W. F. Hegel, Hegel and the Human Spirit: A Translation of The Jena Lectures on the Philosophy of Spirit, trans. Leo Rauch, Detroit, Wayne State University Press, I983, p.II2.

39. VPR I7 II $^{\text {. }}$

40. PR $\S_{5}$ I ('The concept of property requires that a person should place his will in a thing, and the next state is precisely the realization of this concept. My inner act of will which says that something is mine must also become recognizable by others'.)

41. PM §490.

42. $\mathrm{PM} \S 428 \mathrm{R}$. 
In addition, even if a person does not succumb to the endless desires of possession, he still faces a critical problem in fostering the self-consciousness of being a free person only through non-human objects. Given that they have no will of being free, non-human objects merely contribute to one's sense of self-worth secondarily or indirectly. What is confirmed and then mirrored back by them is an image of a person's independence from the selfless and unfree objects that are by nature inferior to human beings. As Allen Wood insightfully observes, 'Even animals, which are living and conscious objects, cannot provide me directly with a sense of my self-worth, since they possess no conception of a free self, and so I can never find in them a confirming perspective on myself'. ${ }^{\prime}$

Since the self-consciousness of being a free person is not fully achievable by a person's sole reliance on an external object, or in other words, a non-I, a person has to seek recourse to 'another I',4 another person with free will. The only 'another I' that can form a full consciousness of being free is another free human being. Gadamer puts this point exceptionally clearly: 'if self-consciousness is to become true self-consciousness, then it must ... find another self-consciousness that is willing to be 'for it"."45 Indeed, Hegel himself explicitly points out that 'Self consciousness exists in and for itself when, and by the fact that, it so exists for another; that is, it exists only in being acknowledged'. ${ }^{4}{ }^{6}$

Hence, the self-consciousness of being a free person reaches its second stage of development, in which 'the objective I acquires the determination of another I, and hence arises the relationship of one self-consciousness to another self-consciousness'. ${ }^{47}$ At this stage, my self-consciousness is recognized by another self-consciousness in a sense that I can perceive my free selfhood reflected back to me out of another self. Both self-consciousnesses (persons) seek to satisfy natural desires, and they achieve it by mutually confirming each other's self-understanding as free beings. In doing so, each self-consciousness must 'come out of itself $4^{8}$ and each must give back the recognition it receives from the other. This is the process of recognition in which two persons are mutually engaged as 'the double movement of the two self-consciousnesses'.9 Both persons simultaneously act as the one being recognized as well the one recognizing.

With respect to property, two persons are mutually engaged in the process of recognition as the owners of objects. Each person recognizes the object(s) possessed by the other as the external sphere of personal freedom. Hegel further points out that 'My existing determinately in my ownership is a relationship to other persons, and from this stems reciprocal recognition: the free is for the free. Since I know myself to be free, I

\footnotetext{
43. Wood, Hegel's Ethical Thought, p.85.

44. PM $\S \$ 29 \mathrm{R}-430$.

45. Hans-Georg Gadamer, Hegel's Dialectic: Five Hermeneutical Studies, trans. P. Christopher Smith, New Haven, Yale University Press, 1976, pp.6i-62.

46. PhG $\$ 178$.

47. PM $\$ 425 \mathrm{R}$.

48. PhG §i79.

49. PhG §I82 ('Each see the other do the same as it does; each does itself what it demands of the other, and therefore also does what it does only in so far as the other does the same. Action by one side only would be useless because what is happen can only brought about by both.). See also, Terry P. Pinkard, Hegel's Phenomenology: The Sociality of Reason, Cambridge, Cambridge University Press, 1994, pp.56-59.
} 
know myself to be universal and know others to be free; and since I know others to be free, I know myself to be free. The principle of right accordingly [runs]: Respect yourself and others in their ownership as persons'.50

With the culmination of mutual recognition, universal self-consciousness of being free begins to take shape in a property-owning society. ${ }^{5 \mathrm{I}} \mathrm{In}$ the process of mutual recognition, one wins freedom for himself not by subjugating the other but only by liberating him, granting him the same free status as he claims for himself, namely an owner of the things in his possession. Given that it is achieved by two property owners on a reciprocal basis, the process of mutual recognition would ripple through the society as a whole as more and more reciprocal parties became involved. In the propertyowning society, every person therefore is intersubjectively recognized by others as a property owner.

We can gain a deeper understanding of Hegel's argument for property and personal freedom from the perspective of his master-slave dialectic. Hegel holds that a slave can foster his self-consciousness of being a free person by working on objects. 'Through work, ... the bondsman becomes conscious of what he truly is... . [1]n fashioning the thing, he becomes aware that being-for-itself belongs to him, that he himself exists essentially and actually in his own right'. Such self-consciousness is fostered among slaves because they undergo the externalizing-and-internalizing-of-their-will process through working on things (e.g., giving forms to or using things). Yet it does not follow that slaves can fully develop their personal freedom. This is because their possession of objects through work is in fact not recognized by the masters who simply treat the slave as their selfless objects. Yet for the masters as well, their ownership of the objects cannot be recognized by slaves, for the latter are treated by the former as selfless objects rather than persons with the self-consciousness of being free. As shown above, mutual recognition is secured between two equal persons. Since slaves are not recognized as persons with the self-consciousness of being free, they are not able to recognize their master's self-consciousness of being free and further his ownership control over objects in his possession.

The master-slave dialectic teaches that the mere act of taking possession of things cannot lead to a fully developed self-consciousness of being free and the legitimation of proprietary control over things. The intersubjectivity of mutual recognition, on the other hand, adds a second dimension to the role of property in building personal freedom: every person promotes the actualization of the self-consciousness of being a free person through being recognized by others as property owners. 'A person, in distinguishing himself from himself, relates himself to another person, and indeed it is only as owners of property that the two have existence for each other..$^{2}$ In this sense, the

50. VPRi7 $\S 3$ I.

5I. According to Hegel, '[u]niversal self-consciousness is the affirmative awareness of oneself in the other self. Each self as free individuality has absolute independence, but in virtue of the negation of its immediacy or desire it does not distinguish itself from the other; it is universal and objective; and it has real universality in the form of reciprocity, in that it is area of its recognition in the free other, and is aware of this in so far as it recognizes the other and is aware that it is free'. PM $\$ 436$. 52. PR $\S 40$. 
property right is not 'actual or objective until it is recognized' 53 and therefore mutual recognition of property is of critical importance to the actualization of personal freedom. To recognize a person as a free being is in fact to recognize the person as free in relation to the things in his proprietary control that constitute the external sphere of personal freedom. In Hegel's view, since the legitimacy of property rights entails the intersubjectivity of mutual recognition, a property-owing society therefore must eliminate the slavery system that erects insurmountable hurdles for realizing mutual recognition of personal freedom.

In short, by going through externalizing and internalizing of free will, and mutual recognition, the two major processes discussed in this section, a person is empowered to become the master of the self or the individual free will, for by doing so he has fully actualized the self-consciousness of being a free person. Given the pivotal importance of having property to actualizing personal freedom, Hegel boldly states 'everyone ought to have property's4 and persons have the 'duty to possess things as property'.55

\section{SHAPING SOCIABILITY: PRIVATE PROPERTY AND THE FREEDOM OF BEING A SOCIAL MEMBER}

\section{A. Social Membership of Ethical Life}

In the preceding section, I discussed the way in which Hegel explores the role of property in developing personal freedom and shaping human individuality. In this realm of Hegel's theory, property owners are seen as persons with private right in the things they possess. Yet being a person is by no means the only identity that the property owner can take on. The identities of human beings, according to Hegel, vary at the different stages of human and social development. When human development proceeds to the stage of ethical life that consists of the institutions of the family, civil society, and the state as 'the unity of ... the will of the individual', ${ }^{6}$ human beings partake of another identity as social members. As Hegel points out, 'In right, the object is the person; at the level of morality, it is the subject, in the family, the family-member, and in civil society in general, the citizen'. ${ }^{57}$ Therefore, in the stage of ethical life, individuals as property owners simultaneously take on social roles as members of the family, civil society, and the state..$^{8}$

\footnotetext{
53. Robert R. Williams, Hegel's Ethics of Recognition, Berkeley, University of California Press i997, p.ior. 54. PR $\$ 49 A$.

55. PM $\S 486$

56. PR $\S 33 \mathrm{~A}$.

57. PR §igo R

58. As to this point, Hegel further explains that 'Individuals as a mass are themselves spiritual natures, and they therefore embody a dual moment, namely the extreme of individuality which knows and wills for itself, and the extremely of universality which knows and wills the substantial. They can therefore attain their right in both of these respects only in so far as they have actuality both as private and as substantial persons'.
}

PR $\oint_{2} 64$. 
To be sure, this transformation of human identity begs the question of why individuals as property owners must see themselves as social members of ethical life. Human beings need the external spheres to develop individuality, and therefore protection of property is of critical importance to promoting personal freedom. Yet Hegel points out that personal freedom 'cannot exist independently' and 'must have the ethical as their support and foundation'. 'Right exists only as a branch of a whole, or as a climbing plant attached to a tree which has firm roots in and for itself' ${ }^{59}$ For Hegel, the actualization of personal freedom is to be socially conditioned, and human beings act as interdependent members of ethical life in a social setting. The social condition of the personal freedom realized in ethical life has two dimensions: the external and internal ethical orders. These two ethical orders make it necessary for individuals to develop their social membership when they pursue their own projects of promoting and protecting personal freedom.

On the one hand, social institutions of ethical life form the external condition for developing personal freedom through the creation of an ethical order of security and stability. Compared to the stage of abstract right in which personal freedom is achieved by the action guided by individual will, ethical life paves the way for developing social wellbeing so as to facilitate the realization of personal freedom for all. In the ethical totality of a society, social institutions are established to promote and protect individual rights as well as the common good. To this end, the creation of social institutions brings about an ethical order in a rational way. The rationality of social order is by nature imbued with 'a fixed content $\ldots$ exalted above subjective opinions and preferences [of individuals]. ${ }^{60}$ Therefore, social institutions in general and laws promulgated by the state in particular create a set of norms with which individuals must comply so as to develop personal freedom collectively in a society. In this way, the ethical order generates a secure and stable environment for developing personal freedom. 'The fact that the ethical sphere is the system of [norms] constitutes rationality. In this way, the ethical sphere is freedom, or the will which has being in and for itself as objectivity, as a circle of necessity whose moments are the ethical powers which govern the lives of individuals. ${ }^{61}$

On the other hand, ethical life brings about the internal ethical order of developing personal freedom. In the stage of pure developing of personal freedom, what human beings achieve is the realization of the self-consciousness of being free. As mere persons, human beings are apt to claim that personal freedom enables them to do whatever they want to do within or even outside of the external spheres that are in their possession. For Hegel, this is the primitive stage of actualizing freedom in that human beings still lack an adequate degree of rationality. Hegel expressly repudiates this sort of claim by stating that 'When we hear it said that freedom in general consists in being able to do as one pleases, such an idea can only be taken to indicate a complete lack of intellectual culture. ${ }^{62}$ Freedom, in Hegel's view, necessarily entails the requirement that

\footnotetext{
59. PR §I4IA.

6o. PR §I 44 .

6I. PR §I 45 .

62. PR $\S_{15} \mathrm{R}$.
} 
human beings make rational choices on a par with the ethical substance of the social whole. Therefore, he states that 'When I will what is rational, I act not as a particular individual, but in accordance with the concepts of ethics in general: in an ethical act.... The rational is the high road which everyone follows and where no one stands out from the rest. ${ }^{\prime}{ }_{3}$ Human rationality, however, is by no means formed naturally. According to Hegel, education (Bildung) plays a pivotal role in shaping human rationality, for the end of education is to cultivate persons with the thinking capabilities that 'regulate one's will according to a universal [principle] ${ }^{6}{ }_{4}$ Such capabilities have formative functions in equipping individuals with an internal ethical order that shows them the ways in which they can reconcile their personal freedom with the external ethical order. ${ }^{65}$ The creation of such an internal ethical order, Hegel observes, is by nature a socially conditioned process. He encapsulates the relationship between education and socially formed human rationality in this way:

The human being who is rational in himself must work through the process of selfproduction both by going out of himself and by education himself inwardly, in order that he may also become rational for himself..$^{66}$

To become rational through education, individuals must acquaint themselves with the major elements of the external ethical order and incorporate them as their inner guidance for their behavior. ${ }^{67}$ These elements may include the law, customs, and traditions in ethical life.$^{68}$ Moreover, individuals rationalize themselves through their social, cultural, and political experiences as members of the family, civil society, and the state.

In short, ethical life, as Hegel shows, is to be created and developed in ways that spark the synergy between the rationality of ethical order and the actualization of personal freedom. To this end, ethical life as the highest stage of human and social development constitutes an interpenetrating unity of objective freedom and subjective freedom. ${ }^{69}$ This is because the rationality of ethical order promotes 'the ability of individuals both to endorse laws and practices that promote the collective good and to find their own particular identities through their social participation..$^{\circ}$ By becoming social members, individuals are deeply ingrained in their externally and internally rational ethical order so as to fully develop their personal freedom. Their social embeddedness shows that the development of social membership and the promotion of individuality can be cross-fertilized and is in fact interconstitutive. As Hegel concludes, 'The right of individuals to their subjective determination to freedom is fulfilled in so far as they belong to the ethical actuality; for

\footnotetext{
63. PR $\S_{15} \mathrm{~A}$.

64. PR $\$ 209$ A. See also, PR $§ \S 187-187$ A.

65 . PhG $\S_{29}$ ('The single individual must also pass through the formative stages of universal Spirit....). 66. PR §IOA.

67. PR §I87 A. See also, Allen W. Wood, 'Hegel on Education', in Amélie Rorty (ed.), Philosophy as Education: Historical Perspectives, London, Routledge, 1998, p.313 ('Bildung is therefore also the development of the capacity and disposition to conform to the rational demands of social life'.).

68. PR §I5I.

69. PR §§8A \& 258.

7o. Neuhouser, Foundations of Hegel's Social Theory, p.I4.
} 
their certainty of their own freedom has its truth in such objectivity, and it is in the ethical realm that they actually possess their own essence and their inner universality'.71

\section{B. Private Property and Social Membership}

The significance of social membership in human development begs the question as to what role property may play in making individuals become the members of ethical life. According to Hegel, property generally plays a dual role in shaping social membership. On the one hand, it lays the foundation for social members to promote their own well-being. On the other hand, it facilitates social recognition of concrete identities that belong to social members.

\section{The Well-Being of Social Members}

The family, civil society, and the state are the three constitutive parts of the Hegelian ethical life. Hegel discusses the ways in which property can be used to promote the wellbeing of social members in the family, civil society, and the state.

a. The Family

For Hegel, the family is the locus in which individuals forge a special relationship based upon love; its members are the husband, the wife, and their children. They work in tandem on a variety of mutual tasks like food preparation, child rearing, and family entertainment. To do so, family members need things like food, water, housing, and so on. Property is crucial to sustaining and enhancing family relationships because it provides the resources on which members of the family draw to accomplish the joint effort of living together and enjoying life. Accordingly, Hegel infers that 'The family, as a person, has its external reality in property; and only in the latter, in the shape of resources, does its substantial personality have its existence.'.72

Family resources are by nature common property to all family members. They are obtained, used, and alienated for the family as a whole. However, property as a family resource still remains private in character and thereby has the power of excluding those who are not members of a particular family. Property in the domain of the family, therefore, is imbued with two characters. It is communal for the family members concerned, and it fosters and promotes the familial relationship in which they are united with a mutual spirit of sharing. On the other hand, it is also private in nature, since the family members need to have this private sphere capable of preserving the intimacy of family life.

\section{b. Civil Society}

Compared to the family, civil society is by nature a marketplace in which its members are involved in various economic relationships in order to satisfy their personal needs. Members of civil society are recognized as private persons. They have their own individual needs and ways to satisfy them. These individual needs are multiplied 
and divided into more particularized concrete needs, and so are the ways to satisfy these particular human needs. ${ }^{73}$ With the proliferation of human needs and the ways of satisfying them, private persons are no longer able to work individually in order to satisfy their needs. Rather, they are engaged in the network of social production and trade of a vast range of goods in the marketplace. Social production and marketbased trade involve the division of labor. Private persons work in the sectors of their specializations..$^{74}$ The products of their work are traded in the marketplace and thereby each private person can obtain a variety of products to satisfy their individualized needs. In this sense, private persons as members of civil society are actually situated in the social network of production and tradeThe property system plays an important role in mediating the process of social work for mass production and trade in the marketplace. Essentially, it forms the transactional basis of the marketplace in which contractual relationships are indispensable to sustaining the flow of trade. As Hegel points out, any contracts presuppose that the contractual parties are property owners because contracts are by nature 'the mediation of the will to give up a property (an individual property) and the will to accept such a property (and hence the property of someone else). ${ }^{75}$ On the other hand, thanks to its communicative function, property facilitates the forming of contractual relationships in the marketplace. In civil society, property comes to have formalities as the proof of the validity of ownership, and thereby the titles become clear in the marketplace. ${ }^{76}$ The trading parties are therefore in a better position to get to know the relevant information about the products that are to be exchanged.

c. The State

Hegel sees the state as the highest sphere of ethical life. 'Since the state is objective spirit, it is only through being a member of the state that the individual himself has objectivity, truth, and ethical life."77 Hegel's view of the nature of the state is sharply different from that of social contract theory which holds that the state is formed by commonality of individual wills. According to Hegel, persons become citizens of the state simply because they have the duty to do so rather than that they choose to do so. ${ }^{78}$ However, persons have the freedom to develop their own individualities and to pursue their own life plans. This is because the progress of the state development cannot be achieved without personal knowledge and volition of the particular individuals who are supposed to engage themselves in different aspects of cultural and political life. Therefore, Hegel points out that the very dynamics of the state 'consists in the unity of its universal and ultimate end with particular interest of individuals, in the fact they have duties toward the state to the same extent as

73. PR §igo-9I.

74. PR §r98; PM §525.

75. PR $\S 74$.

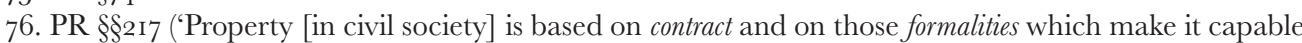
of proof and valid before the law'.) For the discussion about the communicative function of property system, see Carol M. Rose, Property and Persuasion, Boulder, Westview Press, I994, pp.i6-i7.

77. PR $\$ 258$.

78. In the state, 'freedom enters into its highest right, just as this ultimate end possesses right in relation to individuals, whose highest duty is to be members of the state'. PR 258. 
they also have rights.79 This unitary status indicates that the relationship between the state and its citizens is by nature reciprocal. While citizens have the duty to become members of the state, the state has the duty to maintain a stable social environment in a manner conducive to the promotion and protection of personal freedom of citizens.

On the one hand, the use of property can become an important way of delivering citizens' duties to the state. Property protection incentivizes men to actively participate in social and political life and thereby develop political virtue. This positive role played by property has been expounded by the forerunners of republicanism. For example, they thought that 'ownership of property provides the necessary foundation for virtue, enabling citizens to pursue the common welfare. ${ }^{80}$ Citizens also need to perform services for the state. Hegel points out that the state service can be 'expressed in terms of money'. ${ }^{81}$ It can largely be served in the form of one's paying taxes to the state, and taxes are paid by citizens by using their own property.

On the other hand, individuals as the citizens of the state receive legal protection of their civil rights, which is the most important way to promote and protect their personal freedom. Property is one of the most important civil rights protected by the state. Sufficient protection of property is afforded by the state, given the reciprocal relationship with the state and its citizens that was shown above. Yet this reciprocal relationship denotes that it is citizens' membership in the state that entitles them to enjoy the legal protection of property provided by the state. If citizens refuse to become members of the state or withdraw their membership, they would lose their entitlement to state protection of their property. The next section of paper will discuss in detail the ways in which the state provides adequate protection of property rights.

\section{Social Recognition of the Concrete Identity as Social Members}

As shown in section II.B, the upshot of mutual recognition in the stage of personal freedom is that human beings partake of an abstract identity as free persons with property rights. This means that persons are, to some extent, indistinguishable from all others because they are all recognized as purely property owners ${ }^{82}$ By contrast, mutual recognition in the stage of ethical life opens a new chapter of human development: human beings as social members come to be recognized as having concrete identities. They have concrete identities in the sense that they are socially recognized as being fully assimilated into ethical life. For example, in the family, persons act as fathers, mothers, or children; in civil society, persons act as workers, traders, or teachers, among other roles; in the state, persons primarily act as citizens. These are their concrete social roles played by persons as members of ethical life.

79. $\mathrm{PR} \S_{2} 6 \mathrm{I}$

8o. Gregory S. Alexander, Commodity \& Propriety: Competing Visions of Property in American Legal Thought, I776I970, Chicago, University of Chicago Press, 1997, P. 31.

8I. PR §299.

82. See, for example, Neuhouser, Foundations of Hegel's Social Theory, pp. 98-99; Robert B. Pippin, 'What is the Question for which Hegel's Theory of Recognition is the Answer?', 8 European Fournal of Philosophy, vol. 8, no. 2, 2000, p.I64. 
Social recognition of the concrete identity is accomplished by members of ethical life largely through fostering and developing the sense of trust among them. Hegel regards trust as the 'ethical disposition'. Generally, he thinks that trust is nourished among social members in two interlinked ways: first, individuals must be aware of 'the substance and ... identity of all their interests with the whole, $;_{3}^{3}$ and second, the other individuals 'are actual and reciprocally aware of themselves' in the same way. To this end, individuals, first of all, must give up the conception of themselves as mere independent and self-sufficient persons. For example, Hegel points out that the recognition of concrete identities in the family starts from the first moment of love in which an individual does 'not wish to be an independent person in [his] own right and that, if [he] were, [he] would feel deficient and incomplete. ${ }^{84}$ In the state, an individual is supposed to become fully aware that his 'substantial and particular interest is preserved and contained in the interest and the end of an other. ${ }^{85}$ Second, to be recognized by others as a social member, an individual must realize that his carrying out other-regarding activities has intrinsic value to the development of his social membership. To do so, he needs to constantly embrace a sufficient degree of self-reference to the well-being of others. In ethical life, as Hegel observes, 'we are not one-sidedly within ourselves, but willingly limit ourselves with reference to an other, even while knowing ourselves in this limitation as ourselves: ${ }^{96}$ Thirdly, reciprocity is crucial to maintaining trust among social members. This is because an individual's being part of the social whole is premised on the expectation that every other individual would do the same and keep following up. Without a sufficient degree of reciprocity at a social scale, individuals would lack the momentum to transform themselves into social members.

What role can property play in fostering and promoting the trust-based social recognition in the ethical life? As far as I know, Hegel does not explicitly discuss this issue. But we can find clues in this statement:

What predominates in the state is the spirit of the people, custom, and law. There man is recognized and treated as a rational being, as free, as a person; and the individual, on his side, makes himself worthy of this recognition by overcoming the naturalness of his self-consciousness and obeying a universal, the will that is in and for itself, the law; he thus behaves toward others in a manner that is universally valid, recognizing them — as he wishes others to regard him — as free, as persons. ${ }^{87}$

According to this passage, Hegel first emphasizes that every social member must have their own individuality and personal freedom. In other words, one is supposed to be recognized as a free person when he develops his social membership. The inseparability of individuality and sociability, therefore, indicates that the social recognition of concrete identity is attainable under the circumstance in which human beings accomplish the mutual recognition of their abstract identity as free persons. As was shown in the

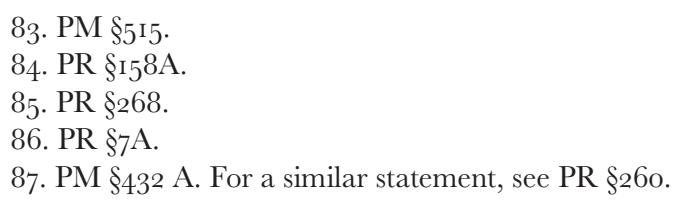


preceding section of this paper, property acts as an indispensable step for human beings to be recognized as free persons. Therefore, having property can be seen as one of the fundamental human conditions under which persons as members of ethical life are empowered to achieve social recognition of their concrete identities.

On the other hand, as the passage above shows, Hegel points out that to be recognized as a social member rather than a purely independent person, one must show to others his acceptance of the ethical substance as intrinsic to his own interest in the sense that he is willing to forgo his private ends when the good of the social whole requires it. In doing so, one also show to others his readiness to overcome the onesidedness of being a mere person and furthermore his sense of the other-regarding virtue. To this end, one can capitalize on property as the medium for showing others his willingness to join social membership and to obey the rule of reciprocity. The voluntary limiting of personal freedom in using property becomes a direct way to show the individual's willingness to become a social member. Property, as shown in section II.A, constitutes the external sphere of personal freedom. Therefore, property is intimately linked to each individual's personal interests. At the same time, it is easy for others to perceive the existence of property as an individual's external sphere of personal freedom. Accordingly, one's readiness to impose self-limitations on personal freedom in using his property is a direct way of showing his readiness to bear in his mind the importance of having the other-regarding virtue. In doing so, one also shows that his engagement in other-regarding activities by no means runs counter to his own personal interests. Rather, he thinks that they have intrinsic value to his self-worth and the development of his social membership. In this regard, Frederick Neuhouser insightfully observes:

Socially free individuals are said to regard their social membership as fundamental to their own 'worth and dignity' and to be motivated to fulfill their roles not out of consideration of 'advantage' but because 'they have their dignity' in doing so. By performing their social roles, and performing them well, they secure the esteem of others and ultimately their self-esteem as well. They achieve, in other words, the recognition of their fellow social members and thereby satisfy an aspiration that Hegel ... regards as fundamental to being a self, namely, the aspiration to be 'someone', to count as a being of value both for oneself and for others. ${ }^{88}$

\section{SOGIAL INSTITUTIONS, PROPERTY RIGHTS, AND ETHICAL DUTIES}

The preceding two sections delved into the role of property in promoting personal freedom and social membership which are interconstitutive in nature. The remaining question is how Hegel would design the building blocks of the property system so as to tap into the power of property in promoting human individuality and sociability. In this section, I aim to address this question by mapping out the landscape of the property system in ethical life that is envisaged by Hegel. Since human beings partake of the concrete

88. Neuhouser, Foundations of Hegel's Social Theory, p.98 (internal quotations omitted). 
identity as social members, the nature of property rights in ethical life sharply differs from that in the stage of personal freedom. On the one hand, there are social institutions created to protect property rights. On the other hand, social institutions impose ethical duties on property owners. Therefore, the actualization of property rights in the social world consists in the combination of rights and duties that are mediated by social institutions aimed at dealing with the vicissitudes of human interactions.

\section{A. Protecting Property Rights}

For Hegel, social institutions are to be constructed with, among other things, adequate safeguards to protect the personal freedom of people in the social whole. For example, Hegel points out that 'In ethical life as a whole, both objective and subjective moments are present, but these are merely its forms. Its substance is the good, that is, the fulfillment of the objective [united] with subjectivity'. ${ }^{89}$ Hegel emphasizes the importance of fulfilling personal freedom in ethical life, because he is fully aware that the development of personal freedom must be sufficiently guaranteed for every individual to promote their social membership. In other words, giving considerable room for an individual to develop his personal freedom or individuality is inextricably intertwined with the shaping of his sociality. In the absence of personal freedom, the machinery of ethical life would lack the very dynamics of making individuals the constituents of the social whole. Take the state as an example. While the state represents the highest stage of development in ethical life, the forming of rational ethical order in the state consists in citizens' self-development and their subsequent participation in cultural and political life. 'The state is the actuality of concrete freedom. But concrete freedom requires that personal individuality and its particular interests should reach their full development and gain recognition of their right for itself'.90 Also, Hegel points out that the end of the state as the actuality of concrete freedom is to achieve the happiness of the citizens'. ${ }^{1}$

Moreover, Hegel specifies the concrete arrangements of social institutions aimed at protecting private rights. First and the foremost, the constitution represents the foundation of the state and the pillar of the rational state order. ${ }^{92}$ It must be designed in a manner conducive to the promotion and protection of personal freedom. 'The constitution of a nation must embody the nation's feeling for its rights and [present] condition'.93 While Hegel does not explicitly discuss whether the constitution needs to contain a clause governing the constitutional protection of property, it is crystal clear that the constitution in general should provide adequate institutional protection of property. This is because Hegel regards property as the most fundamental right vested in human beings. As shown in the preceding two sections of this paper, property lays the foundation for

$$
\begin{aligned}
& \text { 89. PR §I } 44 \mathrm{R} . \\
& \text { 9o. PR §260. } \\
& \text { 91. PR §265A. } \\
& \text { 92. PR §265. } \\
& \text { 93. PR §274A. }
\end{aligned}
$$


individuals to achieve their personal freedom and further promote their social membership in ethical life. For example, Hegel thinks that the success of any economic transactions with contractual relationships lies in the precondition that the parties concerned have properties in their exclusive control. ${ }^{94}$

The constitution, according to Hegel, determines the separation of state powers generally into three parts: legislative power, executive power, and the power of the sovereign. ${ }^{95}$ With respect to the legislative power, it is regarded as the supreme power of the state..$^{6}$ Laws are enacted by the state as a means of specifying the ethical substance and governing the operation of the social whole. ${ }^{97}$ They determine, among other things, 'the benefits which the state enables individuals to enjoy. $9^{9}$ To this end, laws are generally promulgated to protect citizens' civil rights. Therefore, the enactment of civil rightsbased laws is the basic means of providing security and stability of property protection. Moreover, Hegel thinks law generally has three functions:

Laws express the determination of the content of objective freedom. First, for the immediate subject, for his independence willfulness and particular interest, they are restrictions. But secondly they are an absolute final end and the universal work: hence they are produced by the functions of the various estates, which distill themselves more and more out of the universal particularization, and by all the activity and private concerns of individuals. Thirdly, laws are the substance of individuals' free willing within their bounds and of their disposition and so are displayed as prevailing custom. $^{99}$

First of all, laws enacted by the state, according to the above passage, impose restrictions on personal freedom of action. With respect to property protection, persons as individual property owners as well as social members must obey laws to respect others' property rights. Trespassing or any unauthorized use of others' property is generally prohibited by laws. Secondly, Hegel shows that one's acquiescence in laws as a means of respecting others' property rights is in fact the 'universal work' every citizen of the state must engage in. According to Hegel, the infringement of property causes harm not only to an individual property owner but also to the common good as well. 'Since property and personality have legal recognition and validity in civil society, crime is no longer an injury merely to a subjective infinite, but to the universal cause whose existence is inherently stable and strong. This gives rise to the viewpoint that an action may be a danger to society'. ${ }^{100}$ Those who commit infringements of property, therefore, are routinely denounced and penalized by law. Thirdly, laws are largely reflective of the prevailing customs in a society that guide the 'general mode

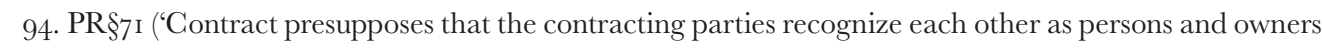
of property...').

95. PR §273.

96. PM § 54IR.

97. PR §298.

98. PR §299.

99. PM $\$ 538$.

IOO. PR 2 I 8 . 
of behavior. ${ }^{\text {ro }}$ Therefore, they embody the safeguards aimed at providing considerable room to accommodate the widely accepted ways of using property. Not surprisingly, Hegel staunchly champions the codification of laws primarily on the grounds that legal codes provide stability and predictability to legal protection of civil rights, including property. ${ }^{102}$

With respect to the executive power, Hegel takes the position that it should be further divided into administrative power and the judicial power. ${ }^{103}$ For the former power, he emphasizes that 'the business of administrators is to look after the private property and interests of these particular spheres, and in this respect, their authority is based in part on the trust of their fellow-citizens and equals. ${ }^{104}$ Regarding the judicial power, courts implement laws and are instrumental in actualizing civil rights. They mediate conflicts of private interests and penalize infringements of property based on the legal norms. By combining the legislative and judicial powers, Hegel concludes, 'infringements of property or personality are annulled..$^{105}$

\section{B. Enforcing Ethical Duties}

While individuals are entitled to adequate legal protection of their property rights, ethical duties are also imposed on them so as to require them to take actions to promote the well-being of their follow members in ethical life and to support the social institutions that provide protection of their rights. Hegel's justification for imposing duties on individuals as social members is derived from the intersubjective nature of the human relationships that are established among them. Given their social membership, individuals are interlocked in different types of human relationships in the fabric of ethical life. Each individual as a social member, in Hegel's view, is empowered to accomplish the pursuit of their ends by their fellow members, with whom they form the social whole in ethical life:

$[\mathrm{H}]$ e cannot accomplish the full extent of his ends without reference to others; these others are therefore means to the end of the particular [person]. But through its reference to others, the particular end takes on the form of universality, and gains satisfaction by simultaneously satisfying the welfare of others. Since particularity is tied to the condition of universality, the whole ... is the sphere of mediation in which all individual characteristics, all aptitudes, and all accidents of birth and fortune are liberated, and where the waves of all passions surge forth, governed only by the reason which shines through them. ${ }^{106} \ldots$ The selfish ends in its actualization, conditioned in this way by universality, establishes a system of all-

\footnotetext{
IоI. PR §I5I.

I02. PR $\S 2$ IIR ('When customary rights are eventually collected and put together - which must happen at an early stage among a people which has attained even some degree of education - this collection is a legal code'); PR § 2IIA (' $[\mathrm{R}]$ ight must be known by thought, it must be a system in itself, and only as such can it have any validity among civilized nations'.); PM $\S 529$.

I03. PR §287; PM §54IR.

I04. PR $\S 288$.

I05. PR §230.

Io6. PR $\$ 182 \mathrm{~A}$.
} 
round interdependence, so that the subsistence and welfare of the individual and rightful existence are interwoven with, and grounded on, the subsistence, welfare, and rights of all, and have actuality and security only in this context. ${ }^{107}$

Being embedded into the human relationships of interdependence, individuals therefore cannot act merely on their natural desires, preferences, or inclinations. Such self-regarding sentiments must be appropriately limited. The creation of self-limitation measures provides individuals with the social experience of learning the ways in which they can limit their personal freedom of action. By going through such experiences, individuals cultivate the other-regarding virtue and the thinking capabilities of sorting out what leads to rectitude. In this sense, one's learning how to limit personal freedom is central to the rationalization of his mind and his development of social membership in ethical life. ${ }^{108}$ 'Without having experienced the discipline that breaks self-will, no one becomes free, rational, and capable of command'. ${ }^{\text {Iog }}$

Therefore, Hegel infers that 'The relations of the individual in the relationships to which the substance particularizes itself constitute his ethical duties. ${ }^{\text {ㅁo }}$ The ethical duties imposed on individuals are conceived of as 'duties of relationships' ${ }^{\prime \prime \prime}$ Moreover, he points out that a person's rights and duties are correlatives rather than opposites: 'duty and right coincide in [the] identity of the universal and the particular will, and in the ethical realm, a human being has rights in so far as he has duties, and duties in so far as he has rights. ${ }^{112}$

For Hegel, ethical duties as the limitations on personal freedom do not put any burden on individuals. Rather, acting as social members, individuals achieve liberation and promote their own well-being through fulfilling their ethical duties. ${ }^{113}$ 'Particularity, limited by universality, is the only standard by which each particular [person] promotes his welfare." ${ }^{114}$ This is because through fulfilling ethical duties, as shown above, one gains independence from the natural desires, preferences, and inclinations, and rationalizes himself through the social experience of engaging in other-regarding activities. On the other hand, one attains the 'objective determinacy of action' getting lost in the search for guidance in the universe of ethical life. For Hegel, ethical duties are reflective of the rational action that social members need to perform regarding the substance of ethical life which lays the foundation for the written laws, customs, and traditions in a society.

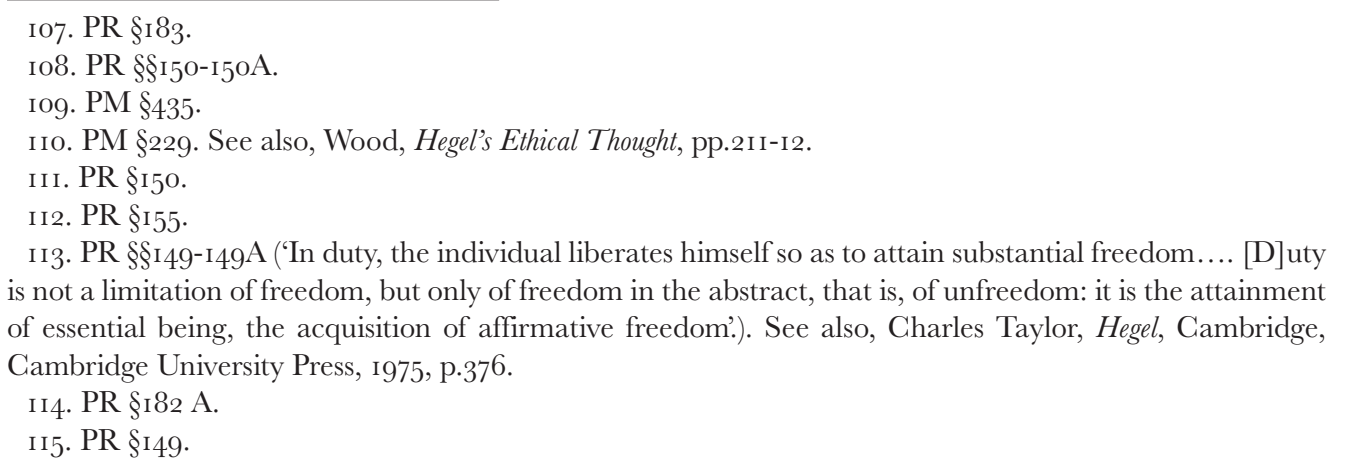


With respect to property, Hegel discusses the basis for imposing ethical duties on property owners. For Hegel, property owners are deeply rooted in social web of human relationships, and therefore have duties to carry out other-regarding activities:

Apart from crimes which the universal authority must prevent or bring to justicei.e., contingency in the shape of arbitrary evil - the permissible arbitrariness of inherently rightful actions and of the private use of property also has external relations with other individuals, as well as with other public arrangements designed to further a common end. Through this universal aspect, private actions become a contingent matter which passes out of my control and which can wrong or harm other people or actually does so. ${ }^{\mathrm{II} 6}$

This view of property-related social relationships has two dimensions. On the one hand, property owners have 'external relations' with other people. This means that the private use of property can produce either positive or negative externalities on others. If a wealthy businessman holds a charity benefit every year in his house or simply donates some portions of his assets, many poor people may benefit from his generosity. But if a person plays loud music at midnight, he will impair his neighbors' sleep and rest. On the other hand, property owners are, to a greater or lesser degree, related to the public policies aimed at promoting and protecting the common good. A factory that discharges a large amount of pollution will cause environmental damage in the region where it is located; a residential community that is designed to be racially exclusive will run counter to the principle of racial equality. These enterprises, albeit privately owned and managed, obviously have some bearing on the public policies aimed at improving environmental protection or racial equality. Therefore, the fact that property owners as social members are constantly engaged in human relationships results in the imposition of different degrees of ethical duties on private use of property. For example, with respect to the ethical duties in the stage of civil society, Hegel observes that 'the individual becomes a son of civil society, which has many claims upon him as he has rights in relation to it... . Civil society must protect its members and defend their rights, just as the individual owes a duty to the rights of civil society'. ${ }^{117}$ Hence, the life cycle of property rights protected by social institutions is incomplete without the accompaniment of the duties imposed on property owners. Rights and duties are constitutive of the property system and are deeply ingrained in a broad range of social settings.

Hegel does not provide a specific and exhaustive list of ethical duties that ought to be imposed upon property owners, and his discussions of these duties are scattered in different parts of the account of ethical life he presents in the Philosophy of Right. In the domain of the family, for example, parents have the duty to physically support other family members and to nurture their children by capitalizing on their proprietary resources. Generally, they have the duty to rear children, cultivate them domestically, and send them to schools for education. ${ }^{118}$

I 6. PR $\$ 232$ (emphases added).

II7. PR $\S \S 238$ \& $238 R$.

II8. PR \$§I $73-75 \& 239$. 
In civil society, individuals have freedom to pursue their own life plans and satisfy their own needs. They bring this to fruition largely by relying on their own resources. The private use of property, therefore, becomes crucial to realizing individual life plans and satisfying individual needs. In this context, everyone has an equal status to pursue their life plans and cannot be arbitrarily interfered with by others. This type of equal status is socially determined, as everyone must be universally aware of the equality of personal freedom of enjoying property rights. Yet private use of property as the means of satisfying individual needs, to a greater or lesser degree, still carries a social character. Hegel explains this point as follows:

Needs and means, as existing in reality, becomes a being for others by whose needs and work their satisfaction is mutually conditioned. That abstraction which becomes a quality of both needs and means also becomes a determination of the mutual relations between individuals. This universality, as the quality of being recognized, is the moment which makes isolated and abstract needs, means, and modes of satisfaction into concrete, i.e. social ones. ${ }^{119}$

Therefore, the individual use of property generally has two characteristics: it is private while also being social. Being private means that an individual can use his property for self-regarding purposes. Yet the social character requires that an individual should be mindful that his private use of property has external effects on others. Therefore, a sufficient degree of other-regarding requirements must be incorporated into the conduct code for property owners. They must use their properties in a manner not harmful to others' enjoyment of their own properties. ${ }^{120}$ For instance, one cannot play loud music at midnight to disturb his neighbors' sleeping in their own rooms.

In the sphere of the state, ethical duties imposed on property owners have intrinsic value to the promotion of their citizenship. Hegel observes that 'The individual, whose duties give him the status of a subject, finds that, in fulfilling his duties as a citizen, he gains protection for his particular welfare, satisfaction of his substantial essence, and the consciousness and self-awareness of being a member of a whole. ${ }^{121}$ Based upon this proposition, Hegel spells out a few circumstances under which the citizens as property owners should be bound by ethical duties. For example, he thinks that speakers as the owners of their speech have the duty to restrain their freedom of expression in certain circumstances. Freedom of expression enjoys a high level protection by the Hegelian state. This is because speech, according to Hegel, is deemed to be the property of speakers. ${ }^{122}$ Yet it does not necessarily follow that every citizen is at liberty to say and write whatever he wishes to. Absolute freedom of expression, in Hegel's view, is hollow in nature and doomed to undermine the intrinsic value of a free society. For example,

II9. PR §ig2.

I20. See, for example, Demarest v. Hardham, 34 N.J. Eq. 469, 474-75 (N.J.Ch. I88I) ('Every man is bound to use his own property in such a manner as not to injure the property of his neighbor').

I2I. PR §26IR.

I22. PR \$3I9 R ('[O]pinion and talk should be highly respected and esteemed on the grounds that the former is personal property of the most spiritual kind, and that the latter is the expression and use of this personal property'.) 
he expressly concludes that 'To define freedom of the press as freedom to say and write whatever one pleases is equivalent to declaring that freedom in general means freedom to do whatever one pleases. Such talk is the product of completely uneducated, crude, and superficial thinking. ${ }^{123}$

Moreover, citizens have the duty to pay taxes as a way to fulfill their state service requirement. ${ }^{124}$ They pay taxes by using their own property. Besides, Hegel discusses the duty of property owners in the circumstance of a state emergency. He holds that individual interest becomes subordinate to national interest in such circumstances. As citizens, property owners have a 'substantial duty ... to preserve ... the independence and sovereignty of the state - even if their own life and property, as well as their opinions and all that naturally falls within the province of life, are endangered or sacrificed?. ${ }^{125}$

Social institutions maintained by the state play an important role in enforcing the ethical duties imposed on property owners. While law provides legal protection of property, it also sets out the limitations on personal freedom. As Hegel observes, 'every genuine law is a freedom, for it involves a rational determination of objective mind, and so a content of freedom. By contrast, nothing has become more common than the idea that each of use must restrict our freedom in relation to the freedom of others, and the state is the condition in which this reciprocal restriction occurs, and the laws are the restrictions. ${ }^{126}$ Ethical duties imposed on property owners, as shown above, are in fact restrictions on personal freedom. Therefore, the spirit and letter of law should aim to enforce the ethical duties imposed on property owners. Also, courts as the institutions that enforce law play an important role in enforcing such ethical duties. On the other hand, administrators are charged with the responsibility to deal with the conflict of private interests, in particular those that are concerned with the community interest. ${ }^{127}$ Acting as the police, some of the administrators are in charge of regulating private uses of property that will potentially cause negative externalities on the well-being of others or the community at large. ${ }^{\mathrm{I} 2} \mathrm{P}$ Put differently, the state has the police power to put private uses of property under its oversight to the extent that such power is exercised to protect 'the safety, health, or morals of the community.'.29

\section{CONCLUSION}

The conventional interpretations of Hegel's property theory, as this paper shows, focus narrowly on the person-to-thing relationship and the role of property in developing

\footnotetext{
I23. PR §319 R.

I24. PR §299.

I25. PR $\$ 324$.

I26. PM $\S 539$.

I27. PR $\S 289$.

I28. PR $\S \S 23 \mathrm{I}^{-} 32$.

129. Mugler v. Kansas, I23 U.S. 623, 664 (I887); Lochner v. New York, I98 U.S. 45, 75 (Holmes J. dissenting) ('It is settled by various decisions of this court that state constitutions and state laws may regulate life in many ways which we as legislators might think as injudicious or if you like as tyrannical as this, and which equally with this interfere with the liberty to contract'.).
} 
human individuality. In this way, they fail to situate their interpretations in the larger picture of Hegel's social theory of freedom, which leads to their inability to reconcile the individualistic aspects of property with Hegel's non-individualistic ideas of ethical life in particular. This is the core problem inherent in the conventional interpretations of $\mathrm{He}-$ gel's theory of property.

In fact, Hegel's theory of property is aimed at tapping into the power of property to foster and promote both human individuality and sociality. The building blocks of social institutions in the Hegelian state act as the indispensable catalyst for engineering the power of property to make personal freedom and social membership interconditioned and interconstitutive.

Property, in Hegel's view, constitutes the external sphere in which a person develops his personal freedom and individuality. In doing so, it further facilitates mutual recognition of personal freedom among persons as property owners. On the other hand, property plays a pivotal role in transforming individuals into social members. In doing so, it promotes the well-being of social members and facilitates social recognition of concrete identities taken on by social members. Moreover, the power of property in shaping human individuality and sociality is indispensably supported by social institutions that function to protect property rights and enforce ethical duties. In the realm of property, Hegel leads us to understand that proprietary control over an external sphere necessarily entails both a person-to-thing relation and person-to-person relations.

Hegel's social theory of property shows how his idea of freedom as 'living with oneself in an other' could be actualized in the social world. As he demonstrates, there is always an other in the freedom sustained and enhanced by the fabric of property relations: persons with things, persons with persons, social members with things, and social members with social members. It is the very otherness embedded into the property that makes the journey to the social world fruitful, exciting, and dynamic. This is because the journey opens a myriad of opportunities for human beings to achieve self-recognition, self-actualization, and self-transformation in social settings. The very immanence of the otherness, as Hegel imaginatively shows, makes us the masters of the self and at home in the social world.

Haochen Sun

Assistant Professor of Law

University of Hong Kong 